\title{
AN OVERVIEW OF 2015 GENERAL ELECTIONS IN NIGERIA
}

\author{
${ }^{1 .}$ Olakunle Olowojolu \\ Department Of Political Science \& International Relations, Landmark University Omu-Aran, Nigeria \\ ${ }^{2}$ Modupe Ake Ph.D \\ Department Of Political Science \& International Relations, Landmark University Omu Aran, Nigeria
}

\begin{abstract}
The attention of the global community will be on Nigeria because it is another electioneering period. Right from the pre-independence era, elections in Nigeria have been characterized by political violence; gross electoral malpractices; government's interference; money politics and the use of ethno-religious identities in shaping the voting patterns of the electorates. Nigeria with a population of over 170 million is fragmented into diverse ethnic groups. The country was conceived by the British Colonialists and till date Nigerians are yet to see themselves as one entity. The results of the 1965 General Elections led to political upheaval that truncated the First Republic after the military organized a coup on January 15, 1966. The Second Republic came to an abrupt end after the military overthrew President Shehu Shagari few months after the 1983 elections. The historic June 12, 1993 election believed to have been won by late Business Mogul, MKO Abiola was considered by many observers as the freest and fairest election in Nigeria's political history. However, the election was infamously annulled by the military dictator, General Ibrahim Babangida. The June 12 annulment shook the foundations of the country as the Babangida regime was forced out, the Interim National Government collapsed less than hundred days and the maximum ruler, General Sani Abacha stepped into power. Since the return to democracy in 1999, elections from the local to national levels suggest that Nigeria's democratic system is still very weak going by the post-election violence that marred the 2011 elections. This research will give an in-depth analysis of the 2015 polls in Nigeria.
\end{abstract}

Keywords: Presidential Elections, Incumbency, Opposition, INEC.

\section{ROAD TO 2015 ELECTIONS}

The 2011 general elections were quite unique in several forms. Firstly, the winner of the presidential contest, Dr. Goodluck Jonathan became the first person from the Niger Delta region to emerge as the executive president of Nigeria. Secondly, the voting patterns during the 2011 presidential election epitomized the influence of ethnicity and religion on Nigeria's electoral system. The Muslim dominated North voted massively for General Muhammudu Buhari (retd) of 
the Congress for Progressive Change (CPC), while the Christian dominated South voted en masse for Dr. Jonathan of the ruling party, People's Democratic Party (PDP) respectively. Thirdly, the post-election violence that erupted after the announcement of Jonathan as winner claimed the lives of about 800 innocent people in Northern Nigeria (Human Rights Watch, 2011).

Between 2011 and 2015, Nigeria had gone through tough times. The escalation of Boko Harm Insurgency in the North, high rate of unemployment, widespread corruption, fragmentation within the major parties and the misconduct of frontline politicians through hate campaigns put the most populous black nation on the spot light both locally and internationally.

There were grave concerns over the conduct and possible outcome of the elections by concerned citizens and the international community. A former Minister of Foreign Affairs, Prof. Bolaji Akinyemi appealed to the major contestants of the presidential election to sign a Memorandum of Understanding (MOU) that will commit them to control their supporters against violence after the 2015 general elections (Punch, December 22, 2014). Similarly, the National Peace Committee for the 2015 General Elections led by former military ruler, General Abdulsalami Abubakar (retd) facilitated peace accord between General Buhari (retd) and President Jonathan (Punch, March 26, 2015).

Concerned that Nigeria could burst into flames, America's Secretary of State, John Kerry flew to Lagos to discuss about the 2015 elections with President Jonathan and General Buhari (retd) respectively (New York Times, January 25, 2015).

The election fever got to its peak after the Independent National Electoral Commission (INEC) announced the postponement of the general elections due to security challenges in the Northeastern zone. The presidential election was shifted from February 14 to March 28, while the governorship and state legislative elections will hold on April 11, 2015 (Vanguard, February 8, 2015). According to INEC, Nigeria's electoral body, 68, 833, 476 Nigerians will be eligible to vote in the 2015 general elections (This Day, 2015 from proposal). Out of the over 68 million registered voters, about 56, 431, 255 people collected their Permanent Voters Cards (PVCs) as indicated by INEC (Vanguard, March 24, 2015).

2015 PRESIDENTIAL ELECTION:

Nigeria's 2015 presidential election was the fifth in a row since the military left the political scene in 1999. PDP which has been the ruling party since 1999 faced its toughest opposition in APC which was formed on February 6, 2013 with the merger of Action Congress of Nigeria $(\mathrm{ACN})$, Congress for Progressive Change (CPC), All Nigeria People's Party (ANPP) and a faction of the All Progressive Grand Alliance (APGA) (The Nation, May 29, 2015).

The March 28 presidential election was quite successful albeit, there were hitches in some polling units across the country due to late the arrival of electoral materials and the ineffectiveness of the Smart Card Readers. Former military ruler, General Muhammudu Buhari (retd) emerged as winner of the presidential election. The election was the fourth time running that Buhari will be contesting as a presidential aspirant. Buhari won with a total number of 
15,424,921 votes as against Goodluck Jonathan's 12,853,162 votes (INEC website). Buhari's historic victory marked the triumph of democracy as it was the first time that an opposition party will upstage the incumbent government in Nigeria through legitimate means.

Figure 1 Map of 2015 presidential election

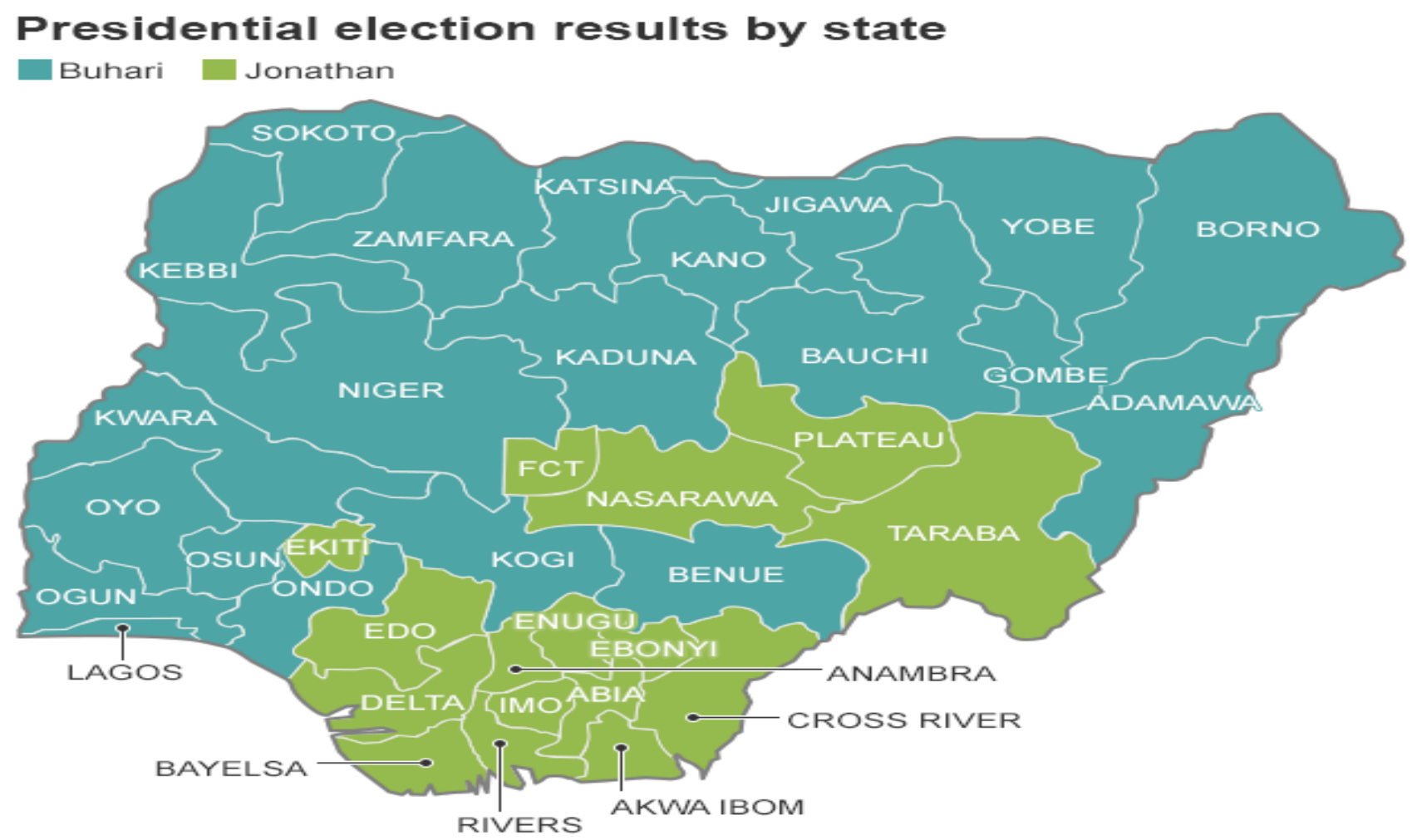

Source: Inec

The breakdown of the 2015 election results show that Buhari won in 21 states of the federation, while Jonathan won in 15 states and the Federal Capital Territory (FCT). In 2011, Buhari won in 12 states in Northern Nigeria, while Jonathan got the highest number of votes in 23 states and the Federal Capital Territory. Osun State was the only exception as it was won by the presidential candidate of the defunct Action Congress of Nigeria (ACN), Mallam Nuhu Ribadu. 
Figure 2 Map of 2011 presidential election

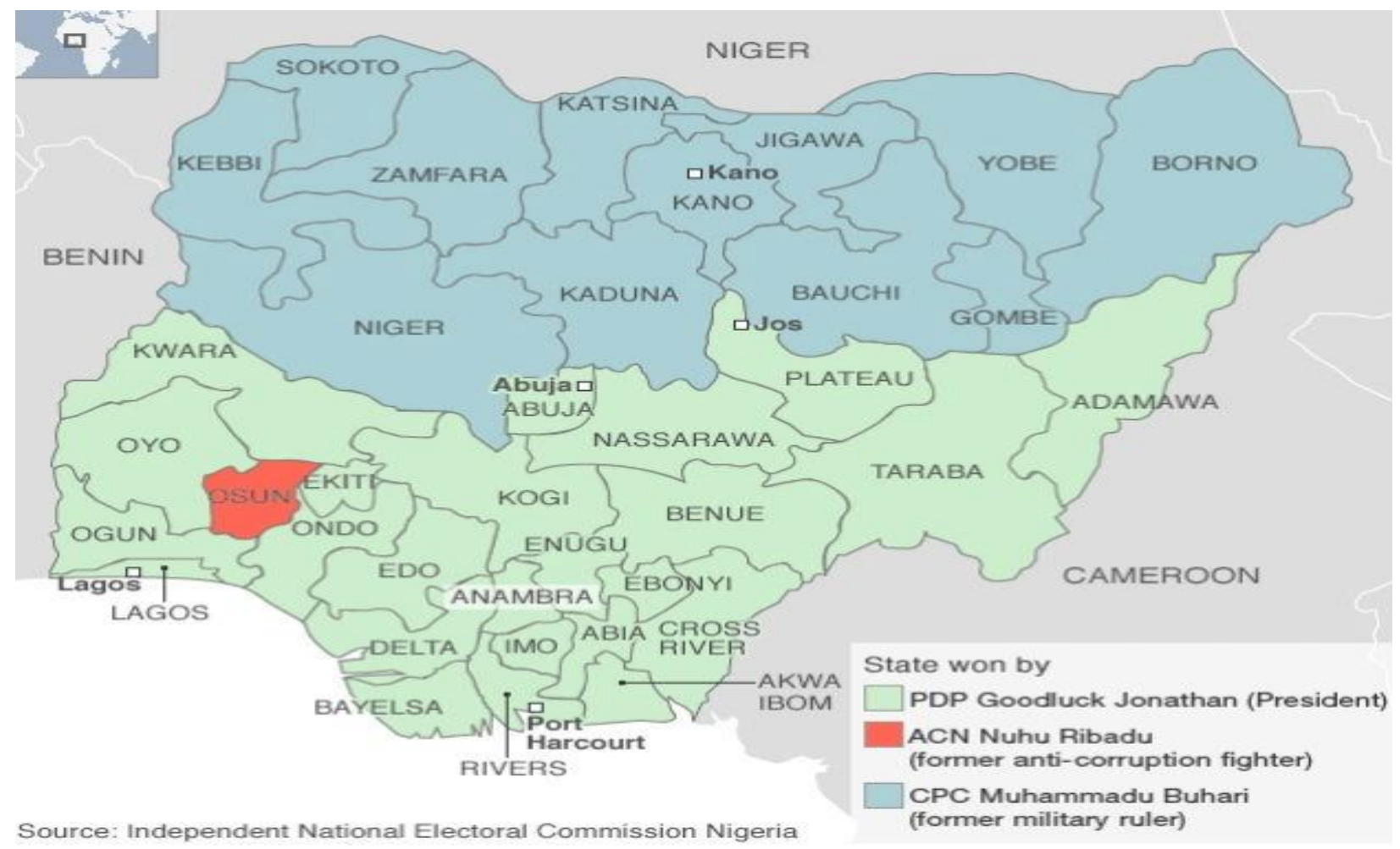

At the 2015 presidential poll, Jonathan (PDP) lost 8 states that it won in four years ago to Buhari (APC). The states include; Adamawa; Kwara; Kogi; Benue; Oyo; Ondo; Ogun and Lagos. Jonathan also lost in Osun as it happened in 2011. However, Ekiti was the only Southwestern state that Jonathan won in 2015. On the other hand, Buhari won massively in the 12 states he won in 2011 as the presidential candidate of CPC. The states include; Sokoto; Kebbi; Zamfara; Niger; Kaduna; Katsina; Kano; Jigawa; Bauchi; Gombe; Yobe and Borno.

At the 2015 presidential election, Jonathan won 14 states and the FCT, a repeat of the 2011 election. The states include; Edo; Delta; Bayelsa; Rivers; Imo; Abia; Enugu; Ebonyi; Akwa Ibom; Anambra; Cross River; Plateau; Nasarawa and Taraba.

Right from the first republic, ethnicity and religion have been key elements that influence voting patterns of Nigerians. Same goes for the 2015 presidential election.

The Muslim dominated North voted massively for Buhari, a native of Daura in Katsina State, while the Christian dominated South-South and South-East regions voted massively for Jonathan who hails from Bayelsa, a state in the South-South. The South-Western states contributed to the victories of Jonathan in 2011 and Buhari in 2015 respectively. The Yoruba ethnic group was all out for Jonathan in 2011, but their voting pattern in 2015 favoured Buhari largely because of the merger that brought Yoruba dominated ACN and the Hausa/Fulani dominated CPC together in forming APC. 


\section{GUBERNATORIAL AND NATIONAL ASSEMBLY ELECTIONS:}

At the gubernatorial elections held in 29 states on April 11, 2015, APC recorded sweet victories in 19 states, while PDP won in 10 states as shown in Table 1. APC got majority seats at the National Assembly. Out of 109 senatorial seats, APC won 64 beating PDP which had 45 seats. At the House of Representatives, APC got 225 seats while, PDP got 125 seats and other parties such as Labour Party, All Progressives Grand Alliance and Accord Party shared the remaining 10 seats. It must be noted that the erstwhile ruling party, PDP has produced all the Speakers of the House of Representatives and Senate Presidents since 1999. However, with the opposition party sweeping the polls, the leadership of the National Assembly will emerge from APC.

Table 12015 Gubernatorial Election Results

$\begin{array}{llllll} & \text { State } & \text { Governor } & \text { Party/Winner } & \text { APC } & \text { PDP } \\ 1 & \text { Abia } & \text { Okezie Ikpeazu } & \text { PDP } & & 264,713 \\ 2 & \text { Adamawa } & \text { Jibrilla Bindo } & \text { APC } & 205,576 & 46,519 \\ 3 & \text { Akwa Ibom } & \text { Udom Emmanuel } & \text { PDP } & 89,865 & 996,071 \\ 4 & \text { Bauchi } & \text { Barr. Mohammed Abubakar } & \text { PDP } & 654,934 & 282,650 \\ 5 & \text { Benue } & \text { Samuel Ortom } & \text { APC } & 413,803 & 173,165 \\ 6 & \text { Borno } & \text { Kashim Shetima } & \text { APC } & 473,543 & 25,640 \\ 7 & \text { Cross River } & \text { Senator Benedict Ayade } & \text { PDP } & 53,983 & 342,016 \\ 8 & \text { Delta } & \text { Senator (Dr.) Ifeanyi Okowa } & \text { PDP } & 67,825 & 724,680 \\ 9 & \text { Ebonyi } & \text { Eng. Dave Umuahi } & \text { PDP } & 27,853 & 289,867 \\ 10 & \text { Enugu } & \text { Ifeanyi Ugwuanyi } & \text { PDP } & 43,839 & 482,277 \\ 11 & \text { Gombe } & \text { Gov Ibrahim Dankwambo } & \text { PDP } & 205,132 & 285,369 \\ 12 & \text { Imo } & \text { Gov Rochas Okorochas } & \text { APC } & 416,996 & 320,705 \\ 13 & \text { Jigawa } & \text { Alhaji Badaru Abubakar } & \text { APC } & 648045 & 479447 \\ 14 & \text { Kaduna } & \text { Nasir El Rufai } & \text { APC } & 1,117,635 & 485,833 \\ 15 & \text { Kano } & \text { Abduallhi Ganduje } & \text { APC } & 1,546,434 & 509,726 \\ 16 & \text { Katsina } & \text { Aminu Masari } & \text { APC } & 943,085 & 476,768 \\ 17 & \text { Kebbi } & \text { Atiku Bagudu } & \text { APC } & 477,376 & 293,443 \\ 18 & \text { Kwara } & \text { Gov Abdulfatah Ahmed } & \text { APC } & 295832 & 115220 \\ 19 & \text { Lagos } & \text { Akinwunmi Ambode } & \text { APC } & 811,994 & 659,788 \\ 20 & \text { Nasarawa } & \text { Umaru Tanko Almakura } & \text { APC } & 191463 & 114674 \\ 21 & \text { Niger } & \text { Abubakar Sani-Bello } & \text { APC } & 593,702 & 239,772 \\ 22 & \text { Ogun } & \text { Gov. Ibikunle Amosun } & \text { APC } & 306,998 & 201,440 \\ 23 & \text { Oyo } & \text { Gov. Abiola Ajimobi } & \text { APC } & 327,310 & 79,019 \\ 24 & \text { Plateau } & \text { Barr. Simon Lalong } & \text { APC } & 564,913 & 520,627 \\ 25 & \text { Rivers } & \text { Nyesom Wike } & \text { PDP } & 124,846 & 1,029,102 \\ 26 & \text { Sokoto } & \text { Speaker Aminu Tambuwal } & \text { APC } & 647,609 & 269,074 \\ 27 & \text { Taraba } & \text { Darius Ishaku } & \text { PDP } & 275,984 & 369,318\end{array}$




$\begin{array}{llllll}28 & \text { Yobe } & \text { Gov Ibrahim Gaidam } & \text { APC } & 334,847 & 179,700 \\ 29 & \text { Zamfara } & \text { Gov Abdulaziz Yari } & \text { APC } & 716,964 & 201,938\end{array}$

Source: APC website- See more at: http://apc.com.ng/index.php/2015-elections/2015-officialelection-results-nigeria-governors\#sthash.oWmZwhOR.dpuf

\section{WOMEN AND THE 2015 NIGERIAN ELECTIONS:}

Few women got elective positions during the 2015 general elections. Out of the 14 contestants for the presidency, only one was a female. At the House of Representatives, just 14 women got voted in, while the remaining 346 are men. Only 7 women will serve as senators in Nigeria's $8^{\text {th }}$ National Assembly comprising of 109 senators. Like in other elections, no woman has broken the jinx of winning gubernatorial election in Nigeria; however, 4 women were elected as Deputy Governors in states such as Lagos, Rivers, Ogun and Enugu respectively.

Table 2 Women Representation in 1999, 2003, 2007, 2011 and 2015 General Elections in Nigeria

\begin{tabular}{|l|l|l|l|l|l|l|l|}
\hline S/ & POSITION & NO OF & NO OF & NO OF & NO OF \\
WVAILAB & WOMEN \\
WOME & WE SEATS & $\begin{array}{l}\text { NO OF } \\
\text { WOME } \\
\text { IN 1999 }\end{array}$ & $\begin{array}{l}\text { N } \\
\text { ELECT } \\
\text { ED 2003 } \\
\text { ELECT } \\
\text { ED IN } \\
2007\end{array}$ & $\begin{array}{l}\text { WLECTE } \\
\text { EL IN } \\
\text { 2011 }\end{array}$ & $\begin{array}{l}\text { ELECTE } \\
\text { D IN } \\
2015\end{array}$ \\
\hline 1 & PRESIDENCY & 1 & NIL & NIL & NIL & NIL & NIL \\
\hline 2 & SENATE & 109 & 3 & 4 & 8 & 7 & 7 \\
\hline 3 & $\begin{array}{l}\text { HOUSE OF } \\
\text { REPRESENTATI } \\
\text { VES }\end{array}$ & 360 & 12 & 21 & 23 & 26 & 14 \\
\hline 4 & $\begin{array}{l}\text { GOVERNORSHI } \\
\text { P }\end{array}$ & 36 & NIL & NIL & NIL & NIL & NIL \\
\hline
\end{tabular}

Source: Author's input

\section{INEC SCORECARD:}

The conduct of the 2015 general elections was far better than the previous elections held in 1999, 2003, 2007 and 2011. The current Chairman of the Independent National Electoral Commission (INEC), Prof. Attahiru Jega showed that he was neither a partisan nor a stooge to Nigeria's political elites. Under his leadership, Nigeria adopted the use of Permanent Voter Card (PVC) and Smart Card Readers in order to curb electoral fraud.

During the presidential and National Assembly elections on March 28, many of the card readers failed to accredit voters successfully. As the tension grew, INEC ordered its electoral officers to do manual accreditation in the affected polling units. The development led to continuation of the exercise in some places the next day, while voters in some areas voted into the night. Despite the uproar over the hitches recorded in the presidential and National Assembly elections, INEC 
insisted that only its card reader would be used, again, for the governorship and state Houses of Assembly elections on April 11 (Punch, May 3, 2015). The general elections received positive remarks from election observers such as ECOWAS, EU, AU and the Commonwealth (Leadership, April 24, 2015).

\section{CONCLUSION AND RECOMMENDATIONS}

The 2015 general elections have been concluded and a new government led by President Muhammudu Buhari has been sworn-in on May 29, 2015. Since the end of the polls, many Nigerians have been basking in the euphoria of the successful transfer of power from one civilian administration to another democratically elected government. Right now, Nigeria is enjoying good will from the international community because of the outcome of the general elections.

Going forward, Nigeria should emulate countries such as Estonia, Namibia and Brazil that have used e-voting successfully. The introduction of PVCs and Card Readers into the 2015 general elections reduced electoral fraud and time wasting. That is an indication that Nigeria can improve through the adoption of advanced ICT in the conduct of elections.

INEC still needs to undergo continuous restructuring especially in areas such as staffing and staff development. INEC should boast of a workforce that is well qualified and efficient. The training of staff is required especially as new technologies are beginning to displace the old methods of conducting elections.

\section{REFERENCES}

Adamu, S. (2015), Appraising The Success of 2015 Elections, Leadership, April 24. http://leadership.ng/features/428153/appraising-the-success-of-2015-elections

Adetayo, O. (2015), Jonathan, Buhari meet again, sign peace accord, Punch, March 26.

Baiyewu, L. (2015), 2015 elections: An X-ray of INEC, Punch, May 3.

http://www.punchng.com/politics/2015-elections-an-X-ray-of-inec/

Eniola, T. (2014), 2015: Akinyemi warns Jonathan, Buhari against violence, Punch, December 22.

Gordon, M. (2015), Kerry Meets With Nigerian Leaders to Encourage Peaceful Election, The New York Times, January 25.

Human Rights Watch (2011). “Nigeria: Post-Election Violence Killed 800.” May 17. http://www.hrw.org/news/2011/05/16/nigeria-post-election-violence-

Killed-800.

The Nation, APC's bumpy journey to power, May 29, 2015.

This Day, INEC Releases Register of Eligible Voters, Candidates, February 28, 2015. http://www.thisdaylive.com/articles/2015-inec-releases-register-of-eligible-voterscandidates/199155/

Vanguard, INEC postpones elections, February 8, 2015.

Vanguard, PVCs: Distribution rate signals robust participation, March 24, 2015.

For more details on 2015 election results, see INEC website. 
APC website- See more at: http://apc.com.ng/index.php/2015-elections/2015-official-electionresults-nigeria-governors\#sthash.oWmZwhOR.dpuf 